\title{
Modelling and Simulation Eutrophication of Water Rivers
}

\begin{abstract}
PETRICA DANIEL TOMA ${ }^{1}$, ADRIANA TOKAR $2 *$, MIRELA SANDA TOROPOC ${ }^{3}$
${ }^{1}$ Apa Nova Bucharest S.A., 60A Tunari Str., 020528, Bucharest, Romania

2Politehnica University of Timisoara, Faculty of Civil Engineering, 2 Traian Lalescu Str., 300223, Timisoara, Romania

${ }^{3}$ Technical University of Civil Engineering of Bucharest, Faculty of Services Engineering, 122-124 Lacul Tei Str., 020396, Bucuresti,

Romania

In this paper presents the mathematical modelling of the flowing river eutrophication process based on model kinetic equations QUAL2E and developed using Scilab-Xcos program. This can be seen graphically by the evolution over time of: algal mass, organic nitrogen, ammonia, nitrite nitrogen, nitrate nitrogen, organic phosphorus, soluble phosphorus, dissolved oxygen concentration and Biochemical oxygen demand for the oxidation of organic substances containing carbon in water of a river, in the case of discharge of a certain wastewater flow untreated, having a certain organic loading.
\end{abstract}

Keywords: eutrophication, flowing water, simulation, QUAL2E, Scilab-XCos

A major problem in water pollution is eutrophication, which is defined as excessive plant growth and / or blooming algae resulting from the super fertilization of rivers, lakes and estuaries [1-5]. Eutrophication generally occurs in lakes, slow-flowing rivers, estuaries, and in particular in delimited water basins [6].

Eutrophication can occur in the form of deterioration in the quality of previously clean water, the generation of bad smelling from plant decomposition and the reduction of dissolved oxygen content in natural water.

Essential conditions for plant and algae growth are suitable macronutrients as nitrogen or phosphorus, sufficient carbon dioxide and light energy. Nitrogen and phosphorus are typically the two key elements in controlling eutrophication.

Another effect of water eutrophication is the increase of turbidity due to the increased density of the phytoplankton developed. By increasing the production of phytoplankton (ie by the consumption of $\mathrm{CO} 2$ ) an increase in the $\mathrm{pH}$ of the water, which, in turn, causes the ammonium $(\mathrm{NH} 4+)$ to pass to the more toxic form of free ammonia (NH3).

Due to the fact that one of the main aspects of the European Water Framework Directive is water quality control, in general, the development of water quality models describing the dynamics or steady state of the main water quality indicators, taking into account mainly the transport phenomena's and treatment processes [1, 7].
So, various methods for modelling river water quality have been developed on the basis of determinant parameters for the calculation of the pollution index [2,3], which usually comprise four of the essential nutrients, namely: phosphorus, nitrogen, carbon and silicon. Along with these, because of the live cells, sulphur, iron, manganese, copper, zinc etc. are also incorporated (complementary nutrients) [5].

Along with these topical research, the paper presents the results of the simulation of the Arge $\mathrm{o}$ River eutrophication process based on the data obtained by Apa Nova Bucure-ti from biological and chemical analyses.

\section{Experimental part}

The mathematical model of the eutrophication process of a flowing water

In this paper is presented the mathematical modelling, starting from the kinetic equations of the QUAL2E model, according to a scheme in Matlab-Simulink, Fig.1, which permits the simulation of eutrophication in the running water after the discharge of a certain waste water flow, based on the following quality parameters: organic nitrogen, ammoniacal nitrogen, nitrite nitrogen, nitrate nitrogen, organic phosphorus, soluble phosphorus, algal mass, Biochemical oxygen demand for oxidation of organic substances containing carbon and dissolved oxygen concentration.

Starting from the interdependences of the parameters presented in figure 1 , the following equations [ $5,8-13]$ can be written:

$$
\begin{aligned}
& \frac{d C}{d t}=k_{2} \cdot\left(C_{2}-C\right)-k_{1} \cdot L_{c}-\frac{k_{4}}{H}+\left(\alpha_{3} \cdot \mu-\alpha_{4} \cdot \rho\right) \cdot A-\alpha_{3} \cdot \beta_{1} \cdot N_{1}-\alpha_{6} \cdot \beta_{2} \cdot N_{2} \frac{d L_{c}}{d t}=-k_{1} \cdot L_{c}-k_{3} \cdot L_{c} \\
& \frac{d N_{4}}{d t}= \alpha_{1} \cdot \rho \cdot A-\beta_{3} \cdot N_{4}-\sigma_{4} \cdot N_{4} \\
& \frac{d N_{1}}{d t}= \beta_{3} \cdot N_{4}-\beta_{1} \cdot N_{1}+\frac{\sigma_{3}}{H}-F \cdot \alpha_{1} \cdot \mu \cdot A \\
& \frac{d N_{2}}{d t}=\beta_{1} \cdot N_{1}-\beta_{2} \cdot N_{2} \\
& \frac{d N_{3}}{d t}=\beta_{2} \cdot N_{2}-(1-F) \cdot \alpha_{1} \cdot \mu \cdot A
\end{aligned}
$$


$\frac{d P_{1}}{d t}=\alpha_{2} \cdot \rho \cdot A-\beta_{4} \cdot P_{1}-\sigma_{5} \cdot P_{1}$

$\frac{d P_{2}}{d t}=\beta_{4} \cdot P_{1}+\frac{\sigma_{2}}{H}-\alpha_{2} \cdot \mu \cdot A$

$\frac{d A}{d t}=\mu \cdot A-\rho \cdot A-\frac{\sigma_{1}}{H} \cdot A$

Table 1

THE COEFFICIENTS VALUE OF THE REAERATION CONSTANT

\begin{tabular}{|c|c|c|c|c|c|}
\hline No. & $\mathbf{a}$ & b & $\mathbf{c}$ & Application limits & Author \\
\hline \multirow{2}{*}{1} & \multirow{2}{*}{3.93} & \multirow{2}{*}{0.5} & \multirow{2}{*}{1.5} & $\mathrm{H}=0.3 \div 9.14 \mathrm{~m}$ & \multirow{2}{*}{$\begin{array}{c}\text { O'Connor- } \\
\text { Dobbins (1956) }\end{array}$} \\
\hline & & & & $\mathrm{v}=0.15 \div 0.49 \mathrm{~m} / \mathrm{s}$ & \\
\hline \multirow{2}{*}{2} & \multirow{2}{*}{5.026} & \multirow{2}{*}{1} & \multirow{2}{*}{1.67} & $\mathrm{H}=0.61 \div 3.35 \mathrm{~m}$ & \multirow{2}{*}{$\begin{array}{c}\text { Churchill et al. } \\
\text { (1962) }\end{array}$} \\
\hline & & & & $\mathrm{v}=0.55 \div 1.52 \mathrm{~m} / \mathrm{s}$ & \\
\hline \multirow{2}{*}{3} & \multirow{2}{*}{5.3} & \multirow{2}{*}{0.67} & \multirow{2}{*}{1.85} & $\mathrm{H}=0.12 \div 0.73 \mathrm{~m}$ & \multirow{2}{*}{$\begin{array}{c}\text { Owens \& Gibbs } \\
1964\end{array}$} \\
\hline & & & & $\mathrm{v}=0.3 \div 0.55 \mathrm{~m} / \mathrm{s}$ & \\
\hline \multirow{2}{*}{4} & \multirow{2}{*}{5.5773} & \multirow{2}{*}{0.607} & \multirow{2}{*}{1.689} & $\mathrm{H}=0.12 \div 3.48 \mathrm{~m}$ & \multirow{2}{*}{$\begin{array}{c}\text { Bennett and } \\
\text { Rathbum (1972) }\end{array}$} \\
\hline & & & & $\mathrm{v}=0.04 \div 1.52 \mathrm{~m} / \mathrm{s}$ & \\
\hline
\end{tabular}

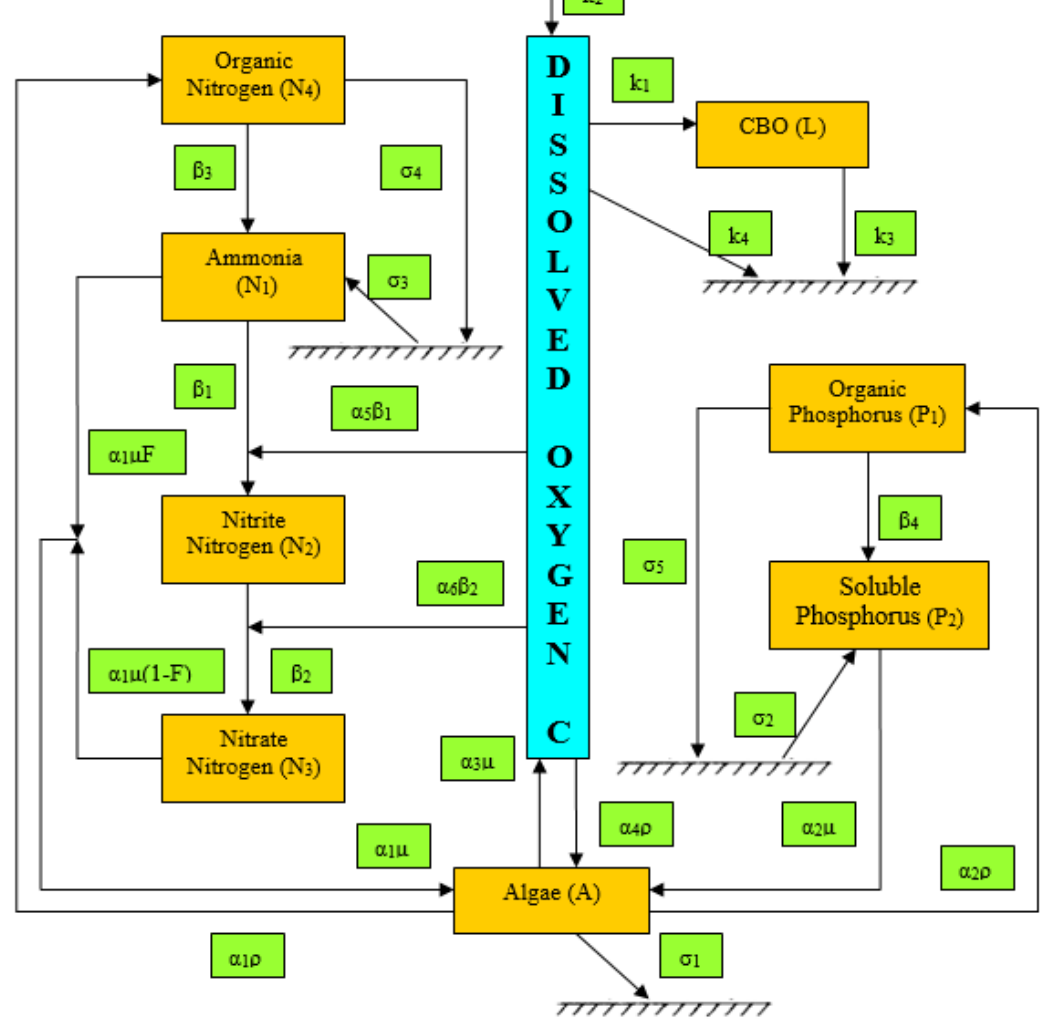

Fig. 1. Schematization interactions for dissolved oxygen balance in QUAL2E model [2].

Fig. 2. Xcos scheme to simulate the eutrophication process and the evolution of the dissolved oxygen concentration in the water of a river. 
The relations and the meanings for defining the cofactors involved in the relations (1) to (9) are specified in [5, 8-12].

As the reduction of eutrophication is dependent on the reactor, the coefficient K2 [13], which occurs in the simulation, in Table 1, its values are displayed at the temperature of $\mathrm{T}=20^{\circ} \mathrm{C}$, determined by various authors.

The calculation relation of water saturation in oxygen, dependent on the average water velocity, has the form [13]:

$$
\mathrm{C}_{3}=14.652-0.41022 \cdot \mathrm{T}+0.007991 \cdot \mathrm{T}^{2}-0.000077774 \cdot \mathrm{T}^{3}
$$

Under the frequent conditions, where there are several sources of impurification (wastewater discharges) with variable flows and charges, the total concentration (C) is determined with the relation:

$$
\mathrm{C}=\frac{\sum\left(\mathrm{C}_{\mathrm{i}} \cdot \mathrm{q}_{\mathrm{i}}\right)}{\mathrm{Q}}
$$

where:

$Q$-total flow;

$q_{i}$-flows of polluting sources;

$C_{\text {- }}$-concentrations of polluting sources.

Based on the above equations, in the Scilab-Xcos program, based on the elements in the scheme show $n$ in figure 2 simulations have been carried out for various temperatures, river water flows and waste water flows, which shows how evolves, in time, concentrations of the organic nitrogen (N4), ammonia (N1), nitrite nitrogen (N2), nitrate nitrogen (N3), phosphorus organic (P1), soluble phosphorus (P2), algal mass (A), Biochemical oxygen demand to oxidize organic substances containing carbon (LC) and oxygen concentration (C) from water.

\section{Results and discussions}

Simulation data, received at S.A Apa Nova Bucharest, for the Arges River, are:

-River flow upstream of the discharge of waste water $Q_{\text {am }}=80 \mathrm{~m}^{3} / \mathrm{s}$;

-Wastewater flow $Q_{2}=5 \mathrm{~m}^{3} / \mathrm{s}$;

$-\mathrm{k}_{\mathrm{u}}(20)=1.1 \mathrm{zi}^{-1} ; a=3.93 ; b=0.5 ; c=1.93 ; v_{c}=0.1 \mathrm{~m} / \mathrm{zi} ;$ $\mathrm{k}_{4}(20)=0.5 \mathrm{zi}^{-1} ; \beta_{1}(20)=0.3 \mathrm{zi}^{-1}, \beta_{2}(20)=1 \mathrm{zi}^{-1}, \beta_{3}(20)=0.5$ $\mathrm{zI}^{-1} ; \beta_{4}(20)=0.3 \mathrm{zi}^{-1} ; \sigma_{1}(20)=1 \mathrm{~m} / \mathrm{zi}^{2} \sigma_{2}(20)=1 \mathrm{mg} * \mathrm{~m} / \mathrm{zi}^{2}$ $\sigma_{3}(20)^{4}=0.001 \mathrm{mg} * \mathrm{~m} / \mathrm{zl}^{1} ; \sigma_{4}(20)=0.05 \mathrm{zl}^{-1} ; \sigma_{5}(20)=0.02 \mathrm{zi}^{-}$ 1; $\mathrm{T}=5^{\circ} \mathrm{C}, 20^{\circ} \mathrm{C} ; \mathrm{H}=3 \mathrm{~m} ; \mathrm{L}^{4}=100 \mathrm{~m} ; \mathrm{k}_{\mathrm{e}}=0.2 \mathrm{~m}^{-1} ; \mathrm{K}_{\mathrm{sn}}=0.015$ $\mathrm{mg} \mathrm{N} / \mathrm{l} ; \mathrm{K}_{\mathrm{sp}}=0.0025 \mathrm{mg} \mathrm{P} / \mathrm{l}$;

-The time for which the simulation $\mathrm{t}=40$ days;

-Minimum daily solar radiation intensity $\mathrm{I}_{0}\left[\mathrm{~W} / \mathrm{m}^{2}\right]$ in the simulated period, has the variation according to figure 3 ; -The time to which the sun sets $t_{a}$, and the sun rises $t_{r}$, in the simulated period, have variations according to the graphs in figure 4 and figure 5;

From the simulation were determined:
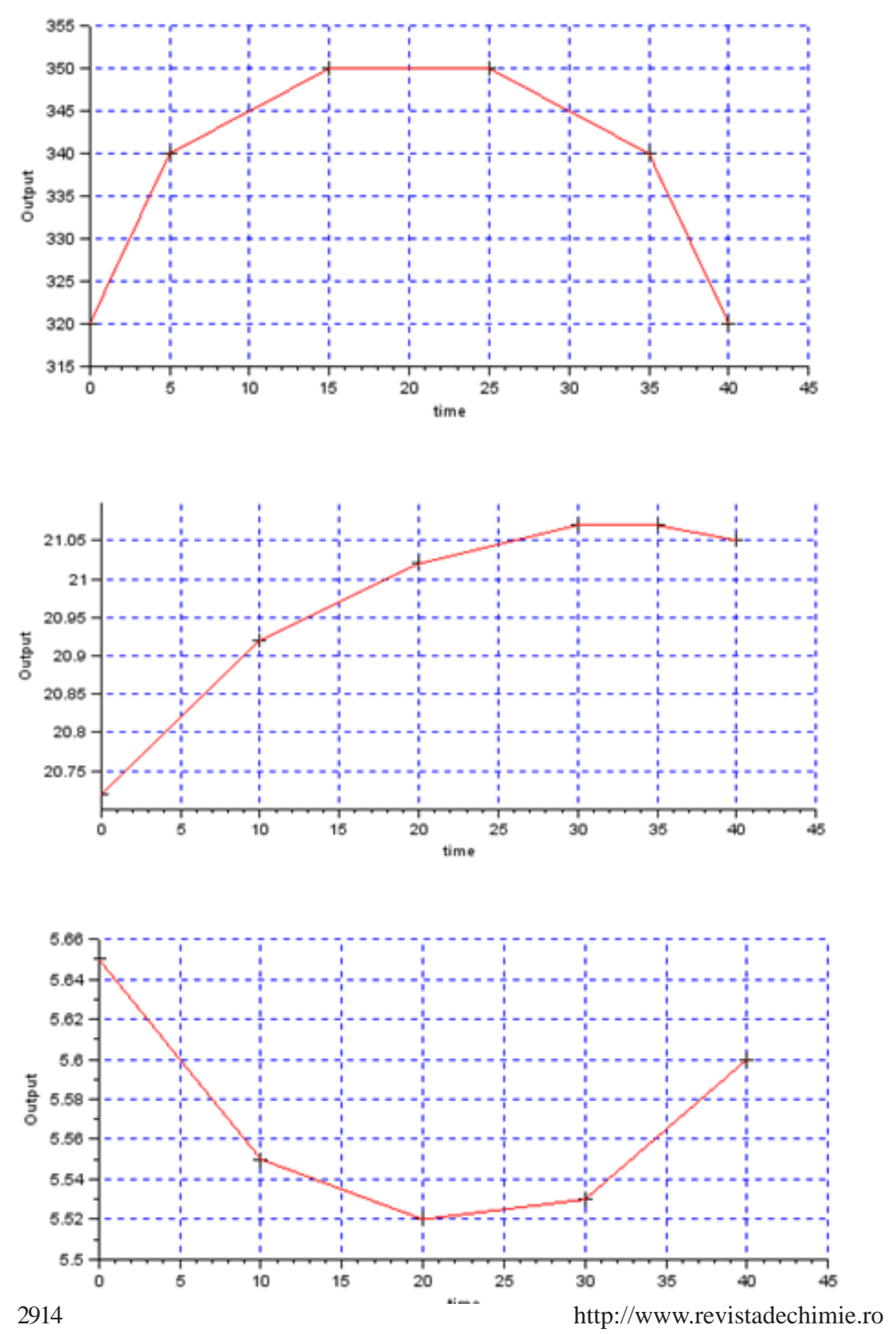

Fig. 3. Evolution minimum daily solar radiation on simulated time.

Fig. 4. The evolution of time that the sun sets in simulated time.

Fig. 5. The evolution of time that the sun rises in simulated time 


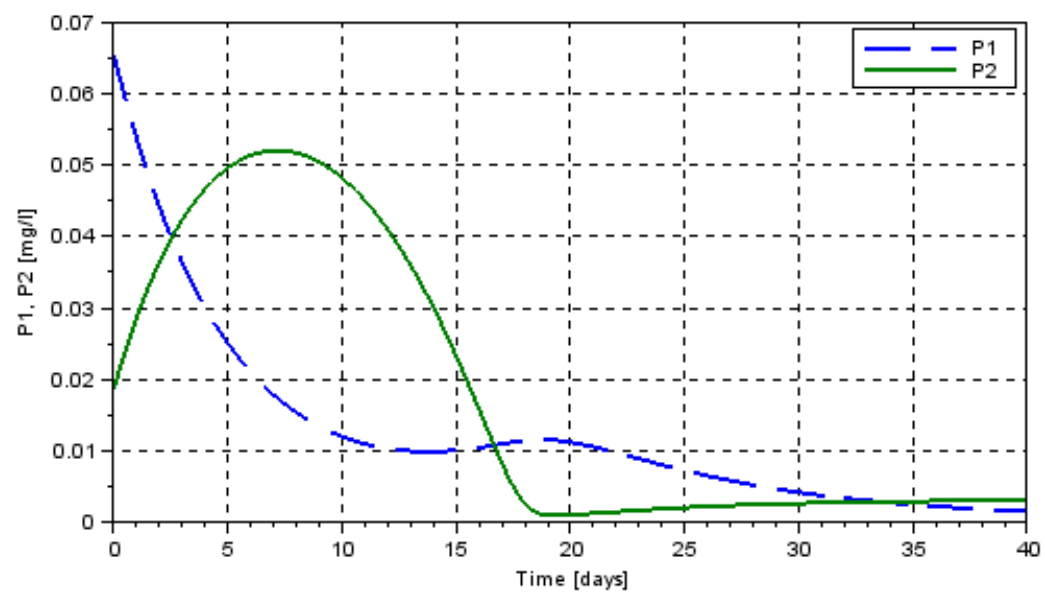

Fig. 6. Evolution of organic phosphorus concentration $\left(P_{1}\right)$ and soluble $\left(P_{2}\right)$ in water of a river over a period of 40 days for water temperature of $10^{\circ} \mathrm{C}$

- Biochemical oxygen demand for the oxidation of carbon-containing substances from water to the wastewater discharge point;

- Concentration of dissolved oxygen from the water to the wastewater discharge point;

- Concentration of organic nitrogen from water to the wastewater discharge point;

- Concentration of ammonia nitrogen from the water to the wastewater discharge point;

- Concentration of nitrite nitrogen from water to the wastewater discharge point;

- Concentration of nitrate nitrogen from water to the wastewater discharge point;

- Concentration of organic phosphorus from water to

the wastewater discharge point;

- Concentration of soluble phosphorus from water to the wastewater discharge point;

- Concentration of algal mass from water to the wastewater discharge point.

For the time period and the water temperatures considered, by simulations the diagrams were obtained of figure 6-8, which give the evolution for: organic phosphorus $(P 1)$, soluble phosphorus (P2), concentrations of organic nitrogen (N4), ammonia nitrogen (N1), nitrite nitrogen (N2), algal mass (A), Biochemical oxygen demand for oxidation of organic substances containing carbon in water (LC), and the concentration of oxygen dissolved in water (C).

From the pollutants analysis (Fig. 6-8) it can be observed that the concentration of soluble phosphorus (P2) has high values during the first 7 days after the discharge of the pollutants, during which time the river has no capacity to self-cleaning, and high values for organic phosphorus (P1) the first days after which the effects of self-cleaning are observed. After 30 days through of the discarged pollutants , under simulated conditions, it is estimated that the organic and soluble phosphorus values approximate to the natural parameters of the emissary.

From the point of view of the impact caused by the concentration nitrate nitrate (N3), a logarithmic evolution is observed throughout the simulated period. The algae
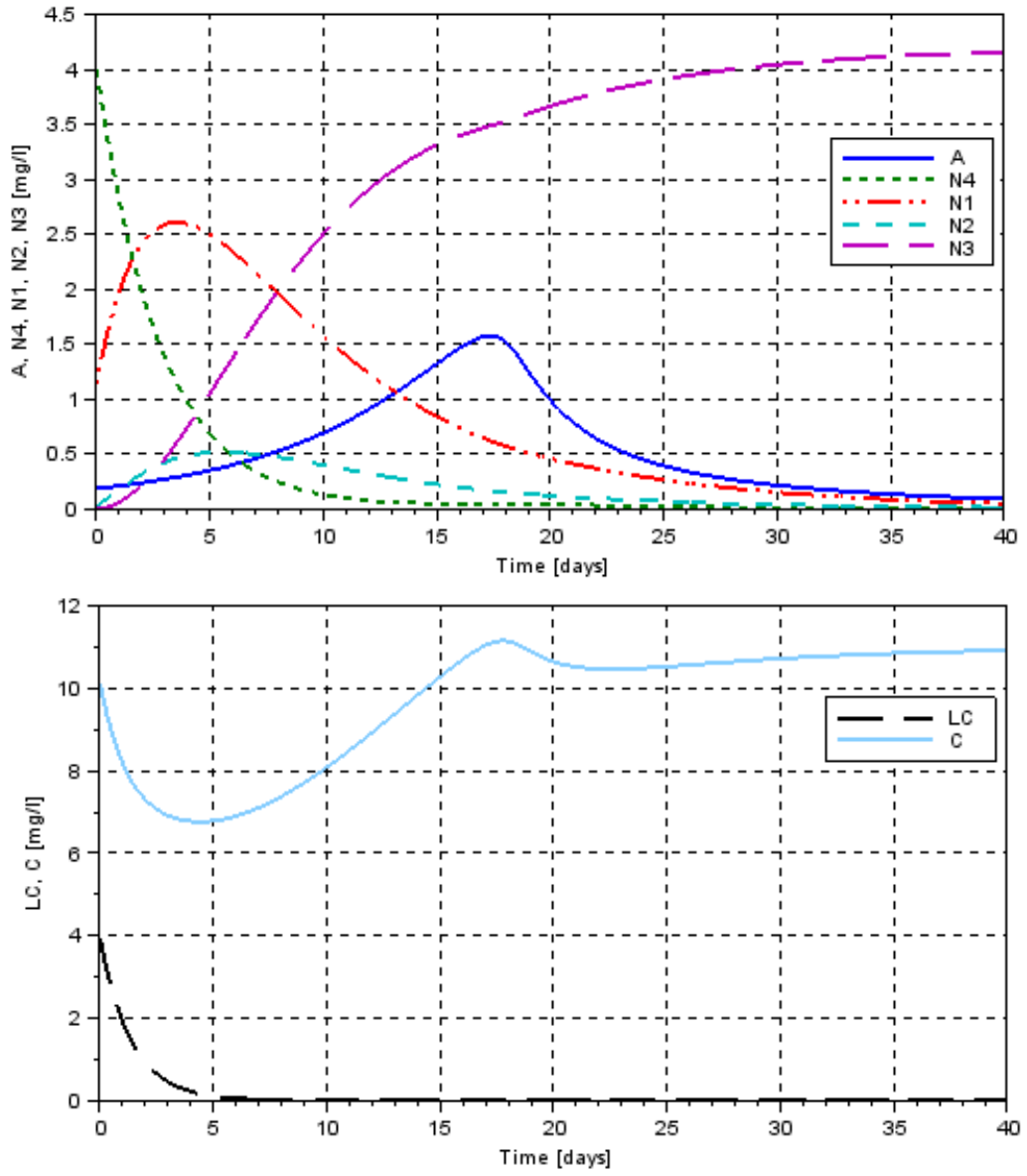

Fig. 7. Evolution of organic nitrogen $\left(N_{4}\right)$, ammonia nitrogen $\left(N_{1}\right)$, nitrite nitrogen $\left(N_{2}\right)$, nitrate nitrogen $\left(N_{3}\right)$ and algae mass concentration $(A)$ of water of a river over a period of 40 days for water temperature of $10^{\circ} \mathrm{C}$
Fig. 8. Evolution of Biochemical oxygen demand consuming substances carbon oxidation $\left(L_{c}\right)$ water and dissolved oxygen concentration $(C)$ in water of a river over a period of 40 days for water temperature of $10^{\circ} \mathrm{C}$ 
mass concentration $(A)$ presents an exponential increase up to the simulated half-time, where it records a maximum, after which due to the self-cleaning capacity, it decreases exponentially to normal values. Concentrations of organic nitrogen (N4), ammonia nitrogen (N1) and nitrite nitrogen (N2) are high within the first 5 days after which, due to the self-cleaning capacity of the river, these concentrations decrease exponentially to normal values.

Biochemical oxygen demand (LC) decreases after 5 days after the pollutant discharge, and the dissolved oxygen concentration (C) presents a uniformity after 20 days.

From the variation in the concentrations of pollutants discharged, the self-cleaning capacity of the flowing waters is demonstrated, but in order to reduce the negative effects in the first 5 days, are necessary measures to reduce the concentrations.

\section{Conclusions}

The mathematical equations solving $(1 \div 9)$ with the program developed in Scilab-Xcos ensures the determination of the variations for: the oxygen concentration in the water of a river $(\mathrm{C})$, Biochemical oxygen demand for the oxidation of organic substances containing carbon in water $(L C)$, organic nitrogen concentrations in water $\left(N_{4}\right)$, ammonia nitrogen $\left(N_{2}\right)$, nitrite nitrogen $\left(N_{2}\right)$, nitrate nitrogen $\left(N_{3}\right)$, organic phosphorus $\left(P_{7}\right)$, soluble phosphorus $\left(P_{2}\right)$ and algal mass concentration $(A)^{2}$.

The program is useful for designing and operating wastewater treatment plant, and simulations can also be made for various time, temperature, river water flows, waste water flow, waste water loads, etc.

On the basis of the data obtained, we appreciate that Scilab-Xcos simulations can also be used to operating water courses to assess the impact of pollution, in order to diminish.

\section{References}

1.DAVID KNEIS, A., A Doctoral Thesis Faculty of Mathematics and Natural Sciences, University of Potsdam, Germany, 2007

2.LAI, Y.C., TU, Y.T., YANG, C.P., SURAMPALLI, R.Y, Kao C.M., J ournal of Hydrology, Vol. 478, 2013, p. 89-101.

3.ROMANESCU, G., TARNOVAN, A., SANDU, I. G., COJOC, G. M., DASCALITA, D., SANDU I., Rev. Chim.(Bucharest), 65, no. 10, 2014, p. 1168.

4.ROMANESCU, G., PASCAL, M., PINTILIE, A. M., STOLERIU, C.C., SANDU, I., MOISII, M., Rev. Chim. .(Bucharest), 68, no. 3, 2017, p. 553. 5.POPA, R., Modelarea calitatii apei din rauri, Editura $* H^{*} G * A *$, Bucuresti, 1998.

6.***M.T.C.T. (Ministerul Transporturilor, Constructiilor si Turismului), Ordin nr. 163 din 15/02/2005 privind aprobarea Reglementãrii tehnice Normativ pentru proiectarea constructiilor si instalatiilor de epurare a apelor uzate orasenesti - Partea a IV-a: treapta de epurare avansata a apelor uzate, indicativ NP 107-04, 2005.

7.LORIN, D., STANCU, A.C., TEUSDEA, V., MITRANESCU, E., CRISTINA, R.T., ORBOI, D., POPOVICI, R.A., PENTEA, M.C., Use of Adapted Diffusion Method as Preliminary Assay for Antifungal Biocides Efficacy Currently Used in Decontamination, Rev Chim. (Bucharest), 66, no. 12,2015 , p. 1978-1981

8.BROWN, L.C., BARNWELL, Jr., T.O., The enhanced stream water quality models QUALE2E and QUQLE2E-UNCAS: Documentation and User Manual. U.S. ENVIRONM. Protect. Agency, Athens, Georgia, 1987. 9.ZHANG, F., A new paradigm of modeling watershed water quality, Dissertation UCFO, 2005.

10.LIN, S. D., Water and wastewater calculations manual, 2 Edition, McGraw-Hill Publishing House, Publisher Lee C.C., 2007.

11.ROBESCU, D., VERESTOY, A., LANYI, S., ROBESCU, D., Modelarea si simularea proceselor de epurare, Editura Tehnica, Bucuresti 2004, p. 22-340.

12.TOMA P.D., J ournal of Environmental Research and Protection, Ecoterra, no. 34, 2013, p. 20-27.

$\overline{\text { Manuscript received: } 16.01 .2019}$ 